\title{
Job Satisfaction and Turnover Intention: The Moderating Effect of Organizational Commitment
}

\author{
Erna Nur Faizah ${ }^{1 *}$, Adi Lukman Hakim², Suryani Yuli Astuti ${ }^{3}$ \\ 1,2,3 Faculty of Economics and Business, Universitas Muhammadiyah Lamongan \\ Lamongan, Indonesia \\ ${ }^{*}$ Corresponding author: \\ Email: faizahnurerna@gmail.com
}

\begin{abstract}
.
Profit organizations or companies engaging in the business world are always triggered to create changes in a wide range of aspects, including managerial policies. It is geared to maintain the organizational sustainability and progress. It is also expected that every change can be favorable in producing organizational effectivity and efficiency at once. The present study examines the moderating effect of organizational commitment on the influence of job satisfaction and turnover intention at PT. Bank Rakyat Indonesia, particularly at the Pontianak branch office in West Kalimantan. A survey is conducted on 30 respondents - the employees of the bank, who are requested voluntarily to fill out the Likert-scale questionnaire. The data is analyzed using a moderate regression and descriptive analysis. The finding reveals that organizational commitment has been identified as a moderator on job satisfaction and turnover intention for the employees of PT. Bank Rakyat Indonesia in the Pontianak branch office.
\end{abstract}

Keywords: organizational commitment, job satisfaction, turnover intention.

\section{INTRODUCTION}

In respect to globalization, easier mobilization demand, and pandemic, there has been a significant escalation in the number of financial intermediation institutions. Originally, customers trust their financial transactions by focusing only on the bank, but nowadays they start to access the online financial management platforms as their assistance. The company needs a sure effort to sustain its existence, and employees could be a choice to bring it into reality. The quality of employees determines the quality of the whole company, their performance and productivity are able to transform as a diversionary element in the business competition. Therefore, it is essential to retain the employees as long as possible, since the cost of reimbursement is the equivalent of hiring new employees.

Typically, before deciding the resignation, employees have the intention to leave. Previous studies claim that turnover intention becomes a strong prediction of resignation. In the beginning, employees thought of leaving their job and attempt to look for another position to reach a decent job. To be more specific, employees, who decide to make an actual turnover, perceive that what is obtained from the current condition is not what they expected. As a result of it, company performance has problems due to employees who perform turnover intention. There is a tendency for 
employees who have high intentions to turnover to take harmful actions in their work environment, e.g., high absenteeism, laziness to work, increased violations of work rules, increased protests against superiors, and different behavior from usual (Harnoto., 2002). Robbins (2013) clarifies that individual withdrawal from an organization (turnover) could be decided voluntarily (voluntary turnover) and involuntarily (involuntary turnover).

Turnover is closely associated with two factors, which are named as internal dan external factorial group. Internal factors consist of demographic characteristics and personalities. Whereas, external groups include work-life quality, job attitude, person or organizational fit, perceived organizational support, conflict and role ambiguity, job insecurity, and self-development opportunities. Among the two main factorial groups, the study merely focusses on job satisfaction and organizational commitment because previous researches report that the two sub-factors are relevant to turnover intention in one unit. Employees who share organizational commitment, tend to do their job as a team. For instance, they might have pride in the job and organization they work for and feel like have a deep attachment to the organization. Consequently, they, who are satisfied with several aspects of their job, voluntarily address themselves as a part of the organization by adjusting to the objectives of the organization. Within high job satisfaction and organizational commitment as a mediator, they would have a strong intention to stay. Therefore, the turnover intention in here would be at a stable or even low rate.

Job satisfaction has been widely known as a comprehensive component in elevating company performance. Job satisfaction helps employees to work more productive, thus company goals could be achieved with ease. Luthans (2014) states that job satisfaction includes reaction, cognitive, affective, and behavior, it also represents the joy or positive emotion which emerges from the employee assessment and work experience. More specifically, the more aspects of work that conform to the individual's desires, the high satisfaction in a job would also be easier to attain. Instead, the fewer aspects of work are fulfilled, individual job satisfaction would also contribute to the decline.

High and achieved satisfaction has been believed to generate a commitment to the organization. Employee commitment to the company takes a crucial role in determining the success of company goals. According to Sopiah (2012), organizational commitment refers to a degree of trust or acceptance of organizational objectives which determines whether an employee will remain or leave the organization. Following that definition, Panggabean (2006) explains that organizational commitment links between organizational members and the system as a whole.

Empirical similar researches have done a lot, specifically, that makes the organization's commitment an intermediate or intervening variable. All those findings have diverse interpretations, either positive or negative. Shabrina and Prasetio (2018), Utomo and Prasetio (2018), Simone, Planta and Cicotto (2017), also Yuda dan Ardana 
(2017) claim that either job satisfaction or organizational commitment, even the interaction among them, have a negative influence to turnover intention. Kartika and Purba (2018) in her research discover that job satisfaction indirectly relates to turnover intention through a mediating variable or commitment to the organization. It means that the high level of job satisfaction and organization's commitment potentially reduce turnover intention, an employee with high satisfaction and a strong commitment to the organization tends to stay other than walk away from an organization which capable to assist and satisfy his/her need.

Mardyana and Riana (2019) finds that organizational commitment carries a negative impact on the connection between job satisfaction and turnover intention. It could be interpreted that elevated job satisfaction potentially influences the increased number of an organization's commitment and potentially lowered its bending to get out of the organization. This study is restricted in the general use of the organizational commitment variable. Moreover, Putra and I Made (2015) also investigate the relevance of these three variables. Their study reported that job satisfaction directly affects turnover intention, and commitment to the organization is a supportive variable for the association of job satisfaction and turnover intention. Further, job satisfaction has a positive and significant impact on organizational commitment. Generally, the employees with the desired level of satisfaction on their job have a tendency to be loyal to their company. Next, organizational commitment has a negative effect on turnover intention. Committed workers would suppress their want to leave because they are quite concerned if they get out at the time, then they would no longer find the current advantages. This research proposes suggestions in relevance to the phenomenon. There is a need to narrowing discussion which explores the items of employee satisfaction like wage, incentive, and the others. A communication platform would be necessary for media exchange information between workers. The company also might implement a penal system for those who resigned prior to the agreed period.

The mutual findings have been founded by Susilo and Satrya (2019). They conclude that job satisfaction an organizational commitment has a positive relationship. Both job satisfaction and organizational commitment harm the employee's intention to leave the company - turnover intention. Hidayat (2018) in his study reveals that job satisfaction and organizational are the possible antecedents to increase or decrease the credit of turnover intention. This situation relies on the negative influence of work satisfaction and the organization's commitment to the employee's intention to walk out. The limitations of this study are the determiner of turnover intention variable and cross-section, so that developed problems like causal connections among variables and time are not revealed.

People's Bank of Indonesia or PT. Bank Rakyat Indonesia has been known as one of the largest commercial banks in Indonesia which provides financial management services. This bank has succeeded in opening many branches in various cities throughout the country, including in Pontianak - West Kalimantan. Since 1988, 
BRI has attracted a large number of customers in that region. Hence, this study involves this commercial bank to investigate how the company manages employee turnover intention in order to provide optimal services. Based on the interview sections with HRD staff and supervisors, the bank was experiencing an increasing turnover intention. The data reported from 2015 to 2016 that there was a decrease in the number of employees by 10 people in the bank teller, customer service, and marketing department. Specifically, in early 2015, there were 84 employees, while in early 2016 , there were only 70 employees at that branch office.

Based on the discussions above, the basis of the reviews on the previous studies, and the phenomena occurs in that company, the current research attempt to examine the relationship between job satisfaction, organizational commitment, and the turnover intention of employees of PT. Bank Rakyat Indonesia in the Pontianak branch office. The motivation for conducting this research is to offer a solution for those involved in decreasing employee turnover intention. Therefore, this study is expected to contribute to human resource science, particularly, for those who associate with turnover intention.

\section{METHODS}

The questionnaire is elected for collecting data. It is designed by a closed method and on a scale in response format, particularly in a format of Likert - scale. Formerly, it is distributed directly to the respondents (offline) in order to give a brief explanation about the research and what is expected from them. Therefore, the respondent responses could be obtained quickly, and they could fill the questionnaire accurately regarding the research objectives.

Furthermore, the category of sample in this research is a total sampling, which invite the whole population into the study. Sugiyono (2015) argued that when the number of populations was less than 100, all of them had to involve in the research. this notion became the basis for this technique selection. The researcher, then, involved the entire population as a research sample, those were the 30 employees of PT. Bank Rakyat Indonesia in the Pontianak branch office in West Kalimantan. They are also divided into the tellers, customer service, and marketing departments. Attempting to describe the research aims in minute detail, this study engages two methods of analysis. First, the respondent responses would be defined using descriptive analysis. The score from the questionnaire would, then, be used as a source for processing data using the moderate regression analysis.

\section{RESULT AND DISCUSSION}

The Descriptive statistics outline the responses of respondents to question representing these three variables, namely job satisfaction, organizational commitment, and turnover intention. As the results of the test being tabulated in the following table: 
Table 1. Job Satisfaction (X)

\begin{tabular}{|c|c|c|c|c|c|c|}
\hline \multirow{2}{*}{ Indicators } & \multicolumn{4}{|c|}{ Respondent Responses } & \multirow{2}{*}{ Score } & \multirow{2}{*}{ Criteria } \\
\hline & SA (4) & A (3) & D (2) & SD (1) & & \\
\hline $\begin{array}{l}\text { Employee satisfies with the } \\
\text { job given by the company } \\
\left(\mathrm{X}_{1}\right)\end{array}$ & 0 & 1 & 7 & 5 & 52 & Very Low \\
\hline $\begin{array}{l}\text { Employee satisfies with the } \\
\text { surveillance by the } \\
\text { supervisor }\left(\mathrm{X}_{2}\right)\end{array}$ & 9 & 8 & 6 & 2 & 104 & High \\
\hline $\begin{array}{l}\text { Employee satisfies with co- } \\
\text { worker's relationships }\left(\mathrm{X}_{3}\right)\end{array}$ & 7 & 13 & 5 & 2 & 109 & High \\
\hline $\begin{array}{l}\text { Employee satisfies with a } \\
\text { well-deserved salary }\left(\mathrm{X}_{4}\right)\end{array}$ & 11 & 10 & 6 & 3 & 119 & High \\
\hline $\begin{array}{l}\text { Employee satisfies with } \\
\text { corporate } \\
\text { policies }\left(\mathrm{X}_{5}\right)\end{array}$ & 8 & 8 & 6 & 4 & 102 & Moderate \\
\hline
\end{tabular}

Source: data processed

The average working - satisfaction variable score is 97.2 and falls in moderate categories. It indicates that the employee of PT. BRI in the Pontianak branch office has sufficient satisfaction with their work because of the company's ability to facilitate some of the dimensions of satisfaction. More specifically, employees have enough opportunity to learn, they also quite satisfy with the surveillance system because of technical assistance and motivation, they feel sufficient with cooperative coworkers in providing technical assistance and social encouragement. Besides, they quite satisfy with the wages that could afford both necessities and workload. The company, as well as, provides the same promotion opportunities for employees to reach higher janitors, this policy keeps them quite satisfying. Workers, thus, are neither too high nor low for some items that have successfully been sufficient.

Table 2. Organizational Commitment (Z)

\begin{tabular}{|c|c|c|c|c|c|c|}
\hline \multirow{2}{*}{ Indicators } & \multicolumn{4}{|c|}{ Respondent Responses } & \multirow{2}{*}{ Score } & \multirow{2}{*}{ Criteria } \\
\hline & SA (4) & A (3) & D (2) & DA (1) & & \\
\hline $\begin{array}{l}\text { Employee has a strong } \\
\text { desire to stay in the } \\
\text { company }\left(Z_{1}\right)\end{array}$ & 0 & 3 & 6 & 7 & 58 & Low \\
\hline $\begin{array}{l}\text { Employee cares about the } \\
\text { company's success }\left(Z_{2}\right)\end{array}$ & 6 & 16 & 6 & 2 & 116 & High \\
\hline $\begin{array}{l}\text { Employee accepts and } \\
\text { abides the values of the }\end{array}$ & 6 & 14 & 8 & 2 & 114 & High \\
\hline
\end{tabular}


company $\left(\mathrm{Z}_{3}\right)$

Employee has a significant 7

17

5

120

High

role and a great

responsibility to the

company $\left(\mathrm{Z}_{4}\right)$

\begin{tabular}{lll}
\hline Average & 102 & Moderate \\
\hline
\end{tabular}

Source: data processed

Table 3 above shows how the employee has a moderate commitment to the company. Referring to the result, it could be described that employees committed enough to maintain their membership going for a long time, to strive in preserving the company's success, to keep the organization's value in common, and to keep the organization's aim in common. In other words, the employee's commitment to the company is neither too high nor low, they have sufficient trust and acceptance to the company has.

Table 3. Turnover Intention (Y)

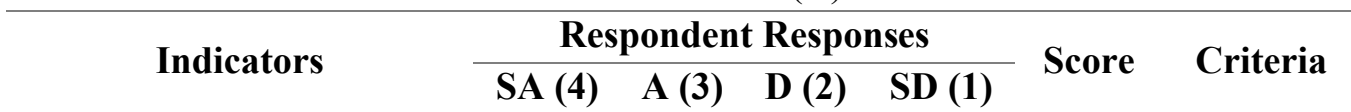

Employee feels lazy at work $\left(\mathrm{Y}_{1}\right)$

12

13

4

126

High

Employee file complaints

with supervisors very often

12

13

4

1

126

High

$\left(\mathrm{Y}_{2}\right)$

Employee are often absent

without notice to the

0

6

6

5

65

Low

company $\left(\mathrm{Y}_{3}\right)$

Employee breaks the company rules very offer $\left(\mathrm{Y}_{4}\right)$

\section{Average}

93.75 Moderate

Source: data processed

The average score for the question of turnover intention is 93.75 and falls in moderate categories. As the result, the employee's moderate turnover intention relies on their desire to leave the company, the desire to find other jobs, absent themselves, and engaging in actions that could expel them from the workplace. It means that if they have a chance to leave the job, they have sufficient notion to prefer it. Moreover, moderate regression analysis is used to test the influence of a causal relationship on this occasion. The results of the test are presented as follows.

Table 4. Moderate Regression Analysis

\begin{tabular}{lccc}
\hline Variables & Coefficient & $\mathbf{t}_{\text {count }}$ & Sig \\
\hline Job Satisfaction $(\mathrm{X})$ & .554 & 4.087 & .001
\end{tabular}




\begin{tabular}{lccc} 
Organizational Commitment $(\mathrm{Z})$ & .513 & 3.046 & .002 \\
\hline Job Satisfaction * Organizational Commitment & .413 & 3.846 & .000 \\
\hline Constant & & & $=5.578$ \\
\hline Adjusted R Square $\left(\mathrm{R}^{2}\right)$ & & $=.535$ \\
\hline Determination $\mathrm{R}^{2}$ & & $=.583$
\end{tabular}

Source: data processed

The table above explains the interaction of job satisfaction and organizational commitment to turnover intention. Based on the result, it concludes that as the interaction of the two variables increases, the employee's turnover intention gets low. The score of determinations R2 denotes the coefficient determination to the role of independent variables related to dependent, the score reaches out 58,3\%. Meanwhile, the adjusted $\mathrm{R}$ square reaches out to $53,5 \%$. The elevation of percentages indicates that adding a moderate variable is used to strengthen the compatibility of job satisfaction and the commitment of an organization with turnover intention. This conclusion has relied on the score of determination R2 after a moderate variable has been included in the equation. As known, the existence of a moderate variable could provide an answer to the question of whether its variable might strengthen or undermine an organization's commitment. Therefore, an organizational commitment includes moderation in the relationship between job satisfaction and turnover intention for the company.

The analysis of $F$ value contains information on whether job satisfaction and organization commitment simultaneously affect both positive and significant to the turnover intention. Based on the measurement, the $\mathrm{F}$ count is reaching out 12.131. The $\mathrm{F}$ comparison, thus, indicates that $\mathrm{F}$ count is greater than the $\mathrm{F}$ table $(12.131>2.93)$. The result of that contrast concludes the acceptance of $\mathrm{Ha}$ and rejection of $\mathrm{H} 0$, the sense that job satisfaction through organizational commitment has a positive and significant influence on the worker's turnover intention.

While an $\mathrm{F}$ value is used to know the influences among variables simultaneously, the $t$ value comparison informs the effect of partial variables. The explanation of partial influences would be divided into several sessions. The first session clarifies the result of testing the influence of job satisfaction on turnover intention. Within a trust level of $95 \%$, it is t table of 2.763 . Next, the statistical measurement reveals the $t$ count of 4.087 with a significant score of .001 (See Table 4). The contrast of $t$ shows that the score of $t$ count is above the score of $t$ table ($4.087>2.763)$ and the significant level is lower than the $5 \%$ tolerance level $(.001<.05)$. This result designates that job satisfaction significantly influences on the turnover intention.

Second, the result of moderate regression also exposes the contribution of organizational commitment to turnover intention. Based on the testing, the $t$ count is 3.046 , and a significant level reaches out .002 . $T$ count, by comparison, is above $t$ table $(3.046>2.763)$ with a degree of significantly lower than a degree of $5 \%$ tolerance 
$(.002<.05)$. Accordingly, it can be enlightened that an organization's commitment has a significant impact on employees' turnover intentions.

The last partial influence is about the interaction of job satisfaction and the organization's commitment to turnover intention. Referring to the result of the regression, the score of $t$ count is 3.846 with .000 significant level. Those scores mean that the $t$ count is higher than the $t$ table $(3.846>2.763)$, and the .000 significant level is below the $5 \%$ tolerance level $(.000<.05)$. Consequently, the moderation variable (interaction between job satisfaction and organizational commitment) partially influences the turnover intention of employees of PT. Bank Rakyat Indonesia in the Pontianak branch office.

Moderate testing is done by contrasting the score of $\mathrm{R}$ square determination (R2), which demonstrates the coefficient determination in the linear and moderate regression. The linear regression gains a coefficient of $57 \%$, meanwhile the moderate regression gains a coefficient of $58.3 \%$. Those scores mean that the coefficient of moderate regression is higher than the coefficient of linear regression. The alternative hypothesis in this case is accepted when the R2 coefficient of moderate testing is above the R2 coefficient of linear regression. The fact displays that there has been a growth in coefficient determinations after a moderate variable has been added, it indicates that organizational commitment is highly possible to strengthen the relation of job satisfaction to turnover intention. The implication of it means that organization's commitment moderates the influence of job satisfaction to turnover intention. Accordingly, organizational commitment has a positive and significant effect on uplifting the contribution among these two variables.

\section{Discussion}

Based on the analysis, the job satisfaction of employees of PT. Bank Rakyat Indonesia in the Pontianak branch office falls into a moderate category. It means that employees are sufficiently satisfied with several items which create their satisfaction not too high or too low. It also shows that some elements of satisfaction have been fulfilled by the company, which employees expected have met what the company provided. These achievements are capable to encourage them to complete their work activity properly. It could be denied that job satisfaction steams from the employees' expectation and the realities felt by them (Sutrisno, 2017).

More specifically, there are numerous items with high scores regarding the employees' perception of the company. First, employees are satisfied with the surveillance in the company. They assume that the superiors give fair and wise oversight. Employees working under no conditions might acquire debriefing again through a training program in order to scaffold their mindset about the standard of service. Moreover, the supervisor provides technical assistance to those employees who are having trouble meeting the customer's demands, difficulty responding to customer's complaints, or bridging customer's requests who want to consult directly 
with superiors. Consequently, it makes them comfortable and safe during work since they have a good co-operation on their part.

Second, employees have a high level of satisfaction with their coworkers. The relationship among them is conducive and cooperative, they are knowing each other and have intimate communication. They also no hesitate to help their workmates who require technical assistance, e.g., they do not mind swapping off-hours or recess for coworkers in need. Besides, social incentives also show fellow workers, they do not merely keep in touch in managerial issues, but also involve outside corporate managerial operation; for instance, going on vacation, having lunch or break time together, or showing their empathy for others. An informant shows us a group chatting of employees and tells us their intimacy among them. Hence, they value their partners into a high category because they are satisfied with it.

According to salary satisfaction, employees are satisfied with the wages and financial factors provided by the company. Their assessment of this item is high because for them the received salary is appropriate, nominal pay is based on employment and years of service. Besides, the company also facilitates the printing of both financial and non-financial compensation items, which are given on schedule and on time. The finances supported by the company are made up based on the workload and responsibilities that are placed on each employee. The fact that salaries and compensation provide physiological assistance to employees, such as food, clothing, and shelter. in other words, wages and other finery factors have been consistent with employee's expectations, as the result of their evaluation of the item falls to high measures.

The employees are satisfied with the chance to upgrade their employment. Promotion is determined according to work terms and achievements during on duty, and it is executed fairly and transparently. The company implements an open evaluation system, which is potentially be accessed by other employees to see how their coworkers are developing. It is believed to increase their motivation to remain overachieving during work. Along with it, the company is promising for those employees who hold their performance over time, they are easier to get promoted. Certainly, such things make them feel satisfied with a system that is applied to a higher office within the company.

A different response is indicated on the work-related satisfaction item. Employees present assessments indicating that they are deeply dissatisfied with the job. This charge is based on an assumption that those who consider work done to be less interesting and less challenging. The fact shows that the majority of job placement of employees is determined based on their previous skills or experiences, and they also have a background in the discipline of banking or the like. Employees, thus, a rate that working long hours gives them very little opportunity to learn anything new to suit their interests and desires. 
Regarding the evaluation of the organization's commitment, it falls into a moderate category. Employees rate their commitment not too high or too low. A substantial commitment is indicated by their desire to maintain membership for longer periods, to work hard for corporate progress, to have values, and to have common goals. More specifically, there are three items of organizational commitment, which has a high score, whereas one item has a low acquisition. First, high revenue is shown as an indicator of concerns about the company's destiny as one of the company's progress efforts. Their concerns are proven with their ability to reach the minimum customer goals set by the company. It should be noted that despite the growing number of customers per period, however, employees still seek to realize other potential goals within the company. Indeed, it shows a tremendous effort on their part to realize the company's goals.

Another indicator of a high rating category is the value equation between employees and the company. It means that employees are willing to accept and embrace the values and goals of the company. Prevailing norms in the company consist of those of law, ethics, and morals. Indeed, they are determined to work in accordance with the requirements. They feel that they have an important role in the bank, which causes them to contribute highly to giving optimally service and according to an established standard. Besides, they also recognize the full amount of work responsibility in order to accomplish the job within their capacities and areas before a superior comes in to tackle it. Here, then, describes employee's awareness of their work and willingness to take responsibility for the work that has been imposed on them.

Dissimilar to the other three items above, the desire to stay in the company for a relatively long period of time scores in low categories. While employees have the commitment to obey and carry out rules or values in a company, this is not enough to keep them firm in there, and they remain to plan to leave the company. An employee said that he kept about leaving work at this bank by the time they got a new job with more money than what they are currently earning. As a result, they simply work to meet corporate or secular obligations. In the meantime, to work competitively for accomplishments or opportunities for advancement, they tend to be less demanding and less concerned. They considered it as good luck to rise to them since they did not seek to achieve it too much. Thus, employees do not expect to stay in that company for much longer.

The summit to get out or what is known as the turnover intention refers to employee movement leaving the organization by order or voluntarily. Based on the analysis, the intention to leave is in a moderate category. It means that employees have sufficient intention to leave the company. Employees are rated to move when they show slothful, complaining frequently, trespassing, and breaking the rules. The intention of turnover relies on two high - acquisition items and two others low. The low gain was on the employee attendance level. More specifically, orderly workers 
attended and rarely went absent without information to the company. This score is also based on the corporate regulations that link absence and pay deductions, employees, who do not attend without permission, must forego their wages by IDR 162 to IDR 250 per day. Workers who could not comply with absences were given three days to complete them, they were asked to submit a doctor's certificate or the like. Nevertheless, on the day they missed work, was required to send a short message (SMS) or email to their supervisor. Therefore, the rule constitutes an unspecified absences rate, resulting in a low fall in the item.

Similar to low absences rates, the number of employees who break the rules also tends to be low. Workers who work out of accordance with standards are being trained by the watch team, and this experience is certainly found to be more boring for them since they are required to re-read and study the company's rules and standards. In certain categories of violations, they get warnings from a mild to severe category. Penalties relating to memorials, suspension, to termination of the working relationship. Meanwhile, unlike the other two, the item of lazy work because of reference thought elsewhere has a high rating of achievement. This indicates that laziness in working is due to the frequent thought of other work. It is known that employees often lose focus on work and have to redo the job being demanded. Besides, the desire to move is also shown by increasing the number of complaints filed by employees to superiors. An employee even adds that they have a virtual room chat that discusses company anomalies. By mutual agreement or command of some members, they simultaneously file complaints on some matters, such as overextended hours of work that often happen at the end of the year or overtime on the national holidays.

The findings show that all hypotheses developed have been accepted. The analysis reveals that job satisfaction significantly influences employee turnover intention. It indicates that the more workers are satisfied with their job, the lower their intention to leave the company, which means they still want to stay in the workplace as long as the elements of job satisfaction are getting high. The employee who satisfies with the salary, promotion, supervision, coworkers, work, and its content, tends to maintain their membership in the organization (Rodly, 2012). Job satisfaction reflects a psychological variable that the most often examined in a model wanting to leave.

Regarding the test, organizational commitment also brings a negative and significant impact on turnover intention. The implication of it shows that the improved commitment items (affective, normative, and continuity) in an organization could lower the level of employees' desire to quit themselves from the company, and vice versa. Individual and organizational values that go hand in hand prefer to maintain the affiliation rather than side with others (Luthans, 2014; Mathis, L. R, \& Jackson, 2011; Robbins, \& Timothy, 2015). This study intermingles job satisfaction and organizational commitment to stimulate the credit of turnover intention. The measurement states that the interaction of these two independent variables contributes to turnover intention significantly. This conclusion means that commitment to an 
organization plays a vital role in the relationship between employee satisfaction and intention to leave. According to Griffin (2013), organizational commitment is an attitude reflecting on how far an individual or employee knows and keeps in touch with the organization they work for.

\section{CONCLUSION}

The results and discussion enlighten how job satisfaction, organizational commitment, and interaction among them could interfere with employee turnover intention. Hence, there are some conclusions related to this situation. First, the employee satisfies enough with the company's wage, promotion, supervision, coworkers, and work itself. Second, organizational commitment falls into the moderate category, the employee has enough affective, normative, and continuity commitment to the workplace. The credit of turnover intention, also, reaches a moderate category, it can be stated that employees are quite interesting to drive off the company.

A study about the relationship between job satisfaction, organization commitment, and turnover intention also has a mutual conclusion. Job satisfaction and turnover intention have a negative and significant relationship. Organization's commitment influences to turnover intention negatively, high commitment shrinks them for leaving the company that provides them a job. Then, organizational commitment moderates the effect of job satisfaction on turnover intention in PT. Bank Rakyat Indonesia in the Pontianak branch office.

Based on the conclusion above, there are some suggestions for the parties being involved. The company needs to pay more attention or evaluate the fulfillment of job satisfaction items, particularly, providing an opportunity for the employees to explore their interest. The company also requests to improve the employees' commitment to the organization, so that they would prefer to stay for a long time. Besides, the company is able to tighten employee recruiting systems, which require them to last a number of years and increase their bid for promotion. Related to the turnover intention situation, the company needs to investigate or evaluate in-depth in describing the possibilities that made them desire to get out more. The company management is also possible to create employee discipline stricter so that no employees are lazy to work or file complaints. Accordingly, the researchers could further investigate the gray area of this discussion.

\section{REFERENCES}

[1] Harnoto. (2002). Manajemen Sumber Daya Manusia (Edisi Ke-2). Jakarta: PT. Prehallindo.

[2] Hidayat, A. S. (2018). Pengaruh Kepuasan Kerja terhadap Komitmen Organisasi dan Turnover Intention. Jurnal Manajemen Dan Pemasaran Jasa, 11(1), 51-66.

[3] Kartika, G \& Purba, D. E. (2018). Job Satisfaction and Turnover Intention: The Mediating Effect of Affective Commitment. Psychological Research on Urban Society, l(2), 100-106. https://doi.org/10.7454/proust.vli2.34 
[4] Luthans, F. (2014). Perilaku Organisasi (Edisi Baha). Yogyakarta.

[5] Mardyana, I.K.E \& Riana, I. G. (2019). Peran Komitmen Organisasional dalam Memediasi Pengaruh Kepuasan Kerja terhadap Kinerja Karyawan Krisna Oleh-Oleh. EJurnal Manajemen, 8(11), 6825-6846.

[6] Mathis, L. R, \& Jackson, H. J. (2011). Human Resource Management (Edisi 10). Jakarta: Salemba Empat.

[7] Moorhead, G \& Griffin, R. W. (2013). Perilaku Organisasi-Manajemen Sumber Daya Manusia dan Organisasi (Edisi Kese; Salemba Empat., ed.). Jakarta.

[8] Panggabean, M. S. (2006). Hubungan Diantara Keterlibatan Kerja, Kepuasan Kerja, dan Komitmen Organisasi. Jurnal Manajemen Sumber Daya Manusia Dan Organisasi, 1(1), $1-34$.

[9] Putra, I Gst Ag G. M \& Wibawa, I. M. A. (2015). Pengaruh Kepuasan Kerja terhadap Turnover Intention dengan Komitmen Organisasi Sebagai Variabel Intervening Pada PT. Autobagus Rent Car Bali. E-Jurnal Manajemen Unud, 4(4), 1100-1118.

[10] Robbins, S. \& Timothy, A. J. (2015). Perilaku Organisasi (Organizational Behavior). Jakarta: Salemba.

[11] Robbins, S. P. (2013). Perilaku Organisasi. Jakarta: Bumi Aksara.

[12] Rodly, L. A. (2012). Turnover Karyawan Kajian literatur.

[13] Shabrina, D.N \& Prasetio, A. P. (2018). Pengaruh Kepuasan Kerja terhadap Turnover Intention Karyawan Pada PT. Tri Manunggal Karya. Jurnal Mitra Manajemen, 2(4), 252-262.

[13] Simone, S.D., Planta, A. \& Cicotto, G. (2017). The Role of Job Satisfaction, Work Engage-ment, Self-Efficacy and Agentic Capacities on Nurses' Turnover Intention and Patient Satis-faction. Applied Nursing Research, 39, 130-140. https://doi.org/10.1016/j.apnr.2017.11.004

[14] Sopiah. (2012). Perilaku Organisasional. Yogyakarta: CV. Andi Offset.

[15] Sugiyono. (2015). Metode Penelitian Kombinasi (Mix Methods). Bandung: Alfabeta.

[16] Susilo, J \& Satrya, I. G. b. H. (2019). Pengaruh Kepuasan Kerja terhadap Turnover Intention yang Dimediasi oleh Komitmen Organisasional Karyawan Kontrak. E-Jurnal Manajemen, 8(6), 3700. https://doi.org/10.24843/EJMUNUD.2019.v08.i06.p15

[17] Sutrisno, E. (2017). Manajemen Sumber Daya Manusia. Jakarta: Kencana Prena Media.

[18] Utomo, K.H \& Prasetio, A. P. (2018). No Title. ISEI Business and Management Review, 2(2), 5-12. https://doi.org/10.36217/ibmr.v2i2.66

[19] Yuda, I.B.D \& Ardana, I. K. (2017). Pengaruh Kepuasan Kerja dan Stres Kerja terhadap Turnover Intention Pada Karyawan Hotel Holiday Inn Express. E-Jurnal Manajemen, 6(10), 5319-5347. 